\title{
Implications of Vaccinations During the 2009 H1N1 Outbreak and Impact on Future Pandemics
}

\section{By Arthur Dermen \& Sevan Evren}

Months after the panic of the H1N1 pandemic has subsided, the WHO continues to track the steady spread around the world, keenly aware that H1N1 infections have dwindled for the moment. Reports of patients developing drug resistance to Oseltamivir during the course of treatment have trickled $\mathrm{in}^{1,2}$, and one case in an Israeli hospital suggested transmission of a drug-resistant strain of $\mathrm{H} 1 \mathrm{~N} 1$ between patients ${ }^{3}$. Remaining vigilant and prepared for future surges of H1N1 through the implementation of proper vaccination can significantly reduce the number of infections and deaths in the long term.

In the United States, an estimated 70,000 vaccine-preventable deaths occur annually. These cases greatly increase the chances of infecting others and unnecessarily increase health-care costs due to hospitalizations. Despite obvious costs and health benefits, vaccinations have been under attack by anti-vaccination campaigns that rely on the proliferation of misinformation ${ }^{4}$. The Lancet's retraction of Andrew Wakefield's 1998 paper $^{5}$ linking Measles-Mumps-Rhubella (MMR) vaccination with autism has undermined the movement, and has come too late for those infected during the latest measles outbreak in the $\mathrm{UK}^{6}$. Antivaccination movements pose a significant threat to reducing immunization against current and future pandemics, as well as reducing herd immunity against diseases that have largely been eradicated.

Surveys of populations suggest that the decision to decline vaccination is often elicited by a number of factors. Mainly, the populace perceives a low risk of acquiring infection, has a heightened fear of rare or non-existent vaccine side-effects, and an overall mistrust towards government and pharmaceutical companies ${ }^{4}$. Furthermore, individual choices were often influenced by their immediate colleague's own opinions on vaccination. Rectifying these false perceptions would likely be aided by

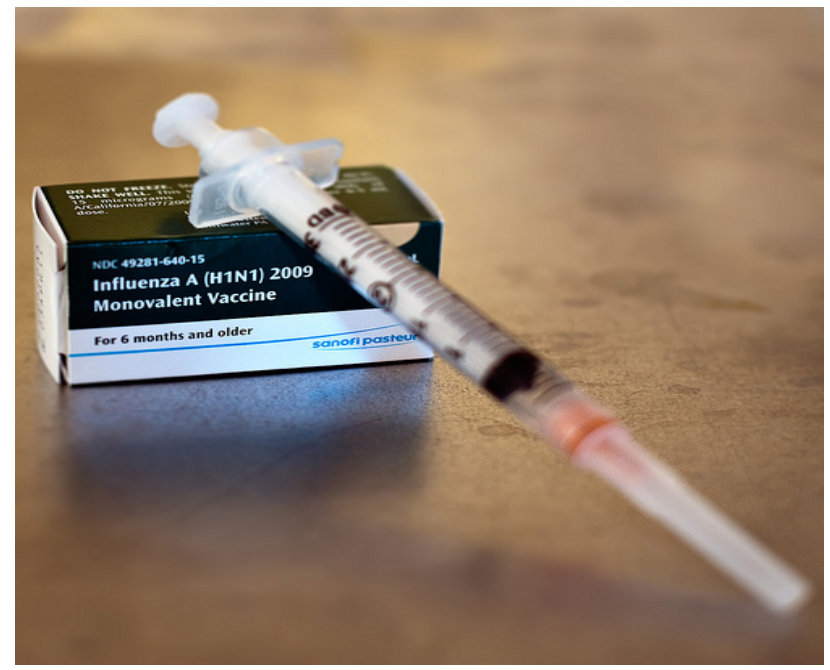

increasing awareness using advertisements through traditional media outlets, such as television ${ }^{7}$. Encouraging vaccination through healthcare workers and hearing out the concerns of people individually are other avenues of reaching out to the populace in a personal and informative way ${ }^{7,8,9,10}$. Furthermore, encouraging leaders and public role models to receive vaccination is another method of directly increasing the intrinsic value of vaccination and encouraging its acceptance among the general population ${ }^{7,11}$. Nonetheless, efforts to vaccinate the population could have limited effect without adequate vaccination of healthcare workers. Adding a specific focus to the immunization of healthcare workers would most likely be beneficial to longterm success in improving vaccination rates.

While some resistance to vaccination has come to be expected in a given scenario, a worrisome trend among healthcare workers has emerged. One study in two Mexican cities found that hospitals had an $80 \%$ vaccination rate during the H1N1 pandemic ${ }^{12}$, leaving 1 out of 5 health-care workers at risk of infection. Similar studies have suggested that rates can drop as low as $50 \%$ in China $^{13}$ and worse, $20 \%$ in Greece ${ }^{14}$. 
Health-care workers have direct exposure to infected patients and as a result, exhibit a high risk of both receiving and transmitting infections. In addition to creating a dangerous route of transmission between high-risk individuals in hospitals, the opinions of health-care workers carry great weight to concerned patients. Addressing the issues that negatively affect vaccination among hospital workers is thus a primary concern.

The lessons from the last decade have been hard learned, but the message for the future is clear. Addressing concerns about vaccine safety and strongly promoting protection against infection can significantly reduce hospitalization and death among the general public and healthcare workers. These benefits extend not only to future epidemics and pandemics, but also diseases that are currently at alltime lows ${ }^{15}$. Furthermore, specific promotion of vaccines among health care workers must also be addressed. Nonetheless, it remains to be seen whether this course of action will be taken before future epidemics and pandemics surface.

\section{References}

1. Cheng PKC, Leung TWC, Ho ECM, Leung PCK, Ng AYY, Lai MYY, Lim WWL. Oseltamivir- and Amantadine-Resistant Influenza Viruses A (H1N1). Emerg Infect Dis. 2009;15(6):966-8.

2. Lackenby A, Hungnes O, Dudman SG, Meijer A, Paget WJ, Hay AJ, Zambon MC. Emergence of Resistance to Oseltamivir among Influenza A $(\mathrm{H} 1 \mathrm{H} 1)$ Viruses in Europe. Eurosurveillance 2008; 13(5):1-2.

3. Mandelboim M, Hindyieh M, Segman-Meningher $T$, Mendelson E. Possible Transmission of Pandemic (HIN1) 2009 Virus with Oseltamivir Resistance. Emerg Infect Dis. 2010. May; [epub ahead of print].

4. Poland GA, Jacobsona RM, and Ovsyannikovaa IG. Trends affecting the future of vaccine development and delivery: The role of demographics, regulatory science, the anti-vaccine movement, and vaccinomics Vaccines, Immunisation and Immunotherapy 200;27(25-26): 32403244.

5. Wakefield AJ, Murch SH, Anthony A, Linnell J, Casson DM, Malik M, Berelowitz M, Dhillon AP, Thomson MA, Harvey P, Valentine A, Davies SE, Walker-Smith JA.. Retraction--Ileal-lymphoid-nodular hyperplasia, nonspecific colitis, and pervasive developmental disorder in children. Lancet. 1998;351(9103):637-41.

6. Jansen VA, Stollenwerk N, Jensen HJ, Ramsay ME, Edmunds WJ, Rhodes CJ. Measles outbreaks in a population with declining vaccine uptake. Science. 2003;301(5634):804.
7. Betz C. Educating the public about H1N1. J Pediatr Nurs. 2009;24(6):445.

8. Miller L, Reynolds J. Autism and vaccination-the current evidence. J Spec Pediatr Nurs. 2009;14(3):166-72.

9. Clements CJ, McIntyre PB. When science is not enough a risk/benefit profile of thiomersal-containing vaccines. Expert Opin Drug Saf. 2006;5(1):17-29.

10. Verstraeten T, Davis RL, DeStefano F, Lieu TA, Rhodes PH, Black SB, Shinefield H, Chen RT; Vaccine Safety Datalink Team. Safety of thimerosal-containing vaccines: a two-phased study of computerized health maintenance organization databases. Paediatrics. 2003;112(5):1039-48.

11. Henderson DA, Courtney B, Inglesby TV, Toner E, Nuzzo JB. Public health and medical responses to the 1957-58 influenza pandemic. Biosecur Bioterror. 2009;7(3):265-73.

12. Esteves-Jaramillo A, Omer SB, Gonzalaz-Diaz E, Salmon $\mathrm{AD}$, et al. Acceptance of a Vaccine Against Novel Influenza A (H1N1) Virus Among Health Care Workers in Two Major Cities in Mexico. Archives of Medical Research 2009;40:705-711.

13. Chor JS, Ngai KL, Goggins WB, et al. Willingness of Hong Kong healthcare workers to accept pre-pandemic influenza vaccination at different WHO alert levels: two questionnaire surveys. BMJ 2009;339 (b): 3391.

14. Mammas IN, Koutsaftiki C, Theodoridou M, Myriokefalitakis N. Vaccination coverage of Greek paediatric healthcare workers against seasonal and A/H1N1 influenza. Acta Pædiatrica 2010. Feb 26 [epub ahead of print].

15. Roush SW, Murphy TV; Vaccine-Preventable Disease Table Working Group. Historical comparisons of morbidity and mortality for vaccine-preventable diseases in the United States. JAMA 2007 14;298(18):2155-63.

\section{Author Profiles}

Arthur Dermen is currently doing research in the area of stem cell biology at the University of Toronto.

Sevan Evren is currently pursuing a MSc degree in Cell and Systems Biology and Developmental Biology at the University of Toronto. His main research interests include cell migration, stem cells, cancer biology, and gastrulation. 